\title{
Before Authorship: Solomon and Prov. 1:1
}

\author{
Jacqueline Vayntrub \\ Brandeis University, USA \\ vayntrub@brandeis.edu
}

\begin{abstract}
How should we understand the naming of legendary figures like Solomon in biblical titles? The ancient practice of attribution is often obscured by scholars committed to the modern construction of authorship. Texts such as 11QPs ${ }^{\mathrm{a}}$ XXVII ("David's Compositions") demonstrate an altogether different understanding of this ancient practice. Using Prov. 1:1 as a test case, this essay examines how biblical authors and editors assigned texts to legendary figures, and how this kind of attribution evokes a set of imagined associations in the broader literary tradition. The essay presents a description and categorization of biblical titles and textual frames, and compares these titles and frames to textual frames of ancient Near Eastern and Mediterranean collections of instruction and poetry. The essay argues that Prov. 1:1, like other textual frames, uses attribution to imaginatively stage the text in the broader literary tradition.
\end{abstract}

\section{Keywords}

Solomon - attribution - titles - paratext - instructions - Proverbs

\section{Introduction}

The title framing the book of Proverbs is deceptive in its simplicity. The title contains two basic elements, a genre term (משלים, "proverbs") and a named

* The author would like to thank those who provided feedback to this study in its various forms, written and presented. Special thanks are due to the organizers and participants of the 2015 SBL Paratexts panel, the 2015 AJs Biblical Biographies panel, and the 2016 NE/EC SBL regional meeting. The author thanks the anonymous reviewers whose comments improved this essay and her research assistant, Anthony Lipscomb. 
individual (Solomon, son of David, king of Israel), joined together in a construct phrase. ${ }^{1}$ Although other similarly structured biblical titles can be found on Song of Songs, Ecclesiastes, individual psalms, and on the frames to some of the prophetic books, such a minimalistic, non-narrative textual frame is unexpected for instruction collections. Nearly all ancient Near Eastern and Mediterranean instruction collections, dating from the third millennium BCE to the first millennium BCE, are framed by a narrative in which the instructions are depicted as the speech performance of a named-and-famed individual. ${ }^{2}$ The title for Proverbs offers no such narrative, leaving us with unanswered questions as to Solomon's function in the frame.

While many understand the ancient reception of Proverbs to claim Solomonic authorship of the book, ${ }^{3}$ modern biblical scholarship has long acknowledged that Solomon's role in the title is not as the work's author. ${ }^{4}$ This long-

1 Fox notes that while this title functions as the book's title in the Talmud, some medieval Jewish commentaries designated the work not by its incipit, but by the phrase ספר חכמה, "The book of wisdom" (as did some early Christian commentators), but also observes that this externally generated title is in fact an interpretation of the book's contents (M.V. Fox, Proverbs 1-9 [Anchor Bible, 18a; New York: Double Day, 200o], p. 53).

2 Crenshaw argues that the very frame of Pirke Avot, a narrative of transmission, places it within the broader ancient Near Eastern wisdom tradition, though he neglects to point out that Proverbs in its present form does not present such a framing device (J.L. Crenshaw, Old Testament Wisdom [Louisville: Westminster John Knox, 2010], p. 5). I discuss the implications of the distinctiveness of the frame of the book of Proverbs in the scholarly reconstruction of ancient Israelite educational practices and institutions in J. Vayntrub, "The Book of Proverbs and the Idea of Ancient Israelite Education," ZAW 128.1 (2016), pp. 96-114.

3 Fox takes the Septuagint's apparent revision of the titles and rearrangement of the sections to be a privileging of Solomonic authorship (Fox, Proverbs 1-9, p. 56), as does Cook ("The Septuagint of Proverbs," in J. Cook and A. van der Kooij [eds.], Law, Prophets, and Wisdom [Leuven: Peeters, 2012], p. 94). Cook sees this singular attribution to Solomon as a deliberate change on the part of the translator. However, the motivations of the translator cannot be determined with certainty; neither can we be sure of the form of the parent text with which the translator was working. Nevertheless, we do observe that the two versions, the MT and LXX, result in different notions of attribution, as the MT cannot be singly attributed to Solomon.

4 This modern scholarly position of Solomonic or Davidic claims to authorship was long anticipated by medieval reception of the biblical materials, which expressed some ambivalence towards Davidic authorship of the Psalms. According to Alastair Minnis, while Ambrose, Augustine, and Cassiodorus believed David was the author of all the psalms, Jerome pointed to two schools of thought on the issue: some thought David to be the author of all the psalms but there were others who understood David to be only one of a number of authors. More sharply, one might also point to the fact that medieval theologians did not give biographical prologues of Solomon to Song of Songs or of David to Psalms. This practice stands in contrast 
standing scholarly consensus was reached by an understanding of the book's organization: the other titles found in the book, Solomonic and otherwise, pointed toward the anthological nature of the book, that it was a collection of multiple, separate works. ${ }^{5}$ As one commentator puts it, "The implication ... is that Solomon is not the 'author,' and that it is not profitable to pursue the question of authorship further." ${ }^{\prime \prime}$ This point is well taken, closing the possibility of a historical Solomon as author. A further line of inquiry, however, is possible: should we expect ancient practices of attribution to conform to our own notions of authorship and intellectual property? That is, did the ancients themselves understand Solomon to be the author of Proverbs, or do their practices of attribution indicate wholly different aims? ${ }^{7}$

It is somewhat commonplace in the modern study of antiquity to sharply contrast modern, Western notions of authorship with ancient attitudes. The title of this essay, "Before Authorship," however, does not imply a linear progression from collective oral tradition to individually authored compositions. The point, rather, is that such titles and their attributions demonstrate distinct attitudes and practices of literary production outside of the category of authorship. Such attributions operate according to a distinctive logic, and this logic may be examined - before the framework of modern, historical-critical scholarship reduces these attributions to unverifiable authorial claims.

to the biographical prologues to Vergil and Ovid. See A.Minnis, Medieval Theory of Authorship: Scholastic Literary Attitudes (Philadelphia: University of Pennsylvania Press, 1988), pp. 43, 47. Note also similarly ambivalent rabbinic views of a singular (Davidic) author of the Psalms in Song of Songs Rabbah: Psalm 30 was understood as the composition of Solomon yet it is nevertheless ascribed to David. Mroczek discusses how Midrash Rabbah to Song of Songs explains the Davidic attribution using the term תלה (lit. "hangs onto"), drawing upon the language of Song 4:4 about the "Tower of David," that אלף המגן תלוי עליו, ("a thousand shields hung upon it"). See E. Mroczek, The Literary Imagination in Jewish Antiquity (Oxford: Oxford University Press, 2016), p. 70.

5 B. Childs, Introduction to the Old Testament as Scripture (Philadelphia: Fortress, 1979), pp. 54559. As early as 1794, Thomas Paine's Age of Reason gives such a reason for doubting the Solomonic authorship of Proverbs and critiquing the work's "keenness" ([New York: Willey Book Company, 190o], p. 24). Eichhorn attributed the anthological nature of Proverbs - like the collection of Psalms, Isaiah, or Daniel - to uniquely ancient practices of text production and preservation: "The golden proverbs of Solomon were from time to time increased by contributions" (J.G. Eichhorn, Introduction to the Study of the Old Testament [trans. G.T. Gollop; London: privately printed, 1888], p. 50).

6 R. Murphy, Proverbs (Word Bible Commentary, 22; Nashville: Thomas Nelson, 1998).

7 Najman has long considered how the practices of attribution in biblical literature make claims beyond authorship. See H. Najman, Seconding Sinai: The Development of Mosaic Discourse in Second Temple Judaism (JSJSup, 77; Leiden: Brill, 2003). 
At the same time, one must keep in mind that these categories and the very act of contrasting "ancient" with "modern" - "them" vs. "us" - are a scholarly practice. Richard Bauman and Charles Briggs explain in Voices of Modernity how the creation of a division between antiquity and modernity and assigning corresponding characteristics are part of the work of constructing modernity itself. $^{8}$ As Haun Saussy indicates, in eighteenth-century European scholarship, the concept of the author was "already profoundly modified ... by making Homer not an individual writer, but the personification of the genius of Greece."'9 J.G. Herder and J.G. Eichhorn configured a clear contrast between the "modern" idea of the author and the "ancient" one. ${ }^{10}$ Recently, scholars in the field of biblical studies as well as those in related fields have come to recognize the constructed nature of these distinctions. Outside the field, a recent study shows how the modern idea of the "author" is not a natural or timeless one, but rather may be traced to developments in the late medieval craft guild and notions of artistic creation and invention that came about in early modern Europe. ${ }^{11}$ To offer one prominent example in biblical studies, Karel van der Toorn's project dismantles an ancient-modern distinction for the purpose of renewing a search for the text's author through tracing the material and cultural practices of text production. ${ }^{12}$ To be clear, van der Toorn's project does not seek to identify individual "authors." Rather, the project pursues historically-critically sound avenues, such as the study of scribalism and the recovery of practices of textual transmission. But such a project is nevertheless concerned

8 R. Bauman and C.L. Briggs, Voices of Modernity. Language Ideologies and the Politics of Inequality (Cambridge: Cambridge University Press, 2003), p. 14. This study has already been productively introduced to biblical scholarship in S. Sanders, The Invention of Hebrew (Chicago: University of Illinois Press, 2009), pp. 14-17.

H. Saussy, The Ethnography of Rhythm: Orality and its Technologies (Fordham University Press, 2016), p. 26.

10 See Eichhorn's articulation of the meaning of "Solomonic" attributions (that "The name of Solomon, the Preacher, belonged to poetry") and generally about ancient literary production (that "it was the custom to arrange old and new together, and to connect with one another what was capable of such disposition"); see Eichhorn, Introduction to the Study of the Old Testament, pp. 26, 49-50. See also Herder's similar understanding of Davidic attribution as an indication of "a beautiful song" and not authorship in The Spirit of Hebrew Poetry. Mroczek describes Herder's understanding in her book as "a theory of Davidic attribution" (Mroczek, Literary Imagination, p. 116).

11 P. Long, Openness, Secrecy, Authorship: Technical Arts and the Culture of Knowledge from Antiquity to the Renaissance (Baltimore: Johns Hopkins University Press, 2001), pp. 23-24. See also the previous study by Minnis, Medieval Theory of Authorship. 
with text production, and not the literary implications of the framing of a given text.

Instead of theorizing ancient conceptions of "authorship" out of practices of attribution, we may do well to set the entire task of theorizing authorship aside, and focus instead on the literary work done by attributions. Or, to follow Foucault's own articulation of the "author-function," which understands attribution as "characteriz[ing] a certain mode of being of discourse,"13 this essay examines how attribution as a literary practice establishes and defines relationships between texts. That is, instead of reconciling ancient practices of attribution with our own notions of authorship, authority, and intellectual property, I seek to sharpen our understanding of how attribution functions literarily. Here I argue that legendary figures like Solomon who are named in textual frames imaginatively stage the text in its broader literary culture.

This study thus focuses on the poetics of attribution in the textual frames of biblical works, examining the beginning of texts (i.e., the titles), material often not considered part of the literary text proper. I present a preliminary categorization of textual frames and argue that what scholars have traditionally understood as ancient designations of authorship might be in fact closer to ancient designations of genre. When scholars rightfully dismiss the text's claims that Solomon is the author of Proverbs or David of Psalms, there is a tendency to exclude titles on historical-critical grounds, and correspondingly, neglect their literary dimensions. Examined from a literary perspective, the titles present an opportunity to understand the conventions and underlying values engaged by the literary tradition. Put differently, when judging the so-called authorial claims of titles to be inauthentic, scholarship still operates within the assumption that these titles in fact claim authorship. This study argues that attribution makes no claims about authorship, at least as this intellectual category functions for the modern reader. Rather, these titles engage the biography of a legendary figure to provide an interpretive frame for the text it contains.

As the preliminary categorization demonstrates below, simple titles like Prov. 1:1 are just one type of textual frame. These frames, in a range of configu-

13 M. Foucault, "What is an Author?," Language, Counter-memory, Practice (ed. D.F. Bouchard; trans. D.F. Bouchard and S. Simon; Ithaca: Cornell University Press, 1977), pp. 113-38. Foucault writes, "Such a name permits one to group together a certain number of texts, define them, differentiate them from and contrast them to others ... it establishes a relationship among the texts." See also R. Chartier, The Order of Books: Readers, Authors, and Libraries in Europe between the Fourteenth and Eighteenth Centuries (trans. L.G. Cochrane; Cambridge: Polity, 1994), p. 29 et passim. 
rations, situate non-narrative literary material - poetry or speeches - in a performance situation, and assign an ideal figure - David or Solomon, for example - to the poetry. This character or ideal figure authorizes and contextualizes the poem, even if this context is not an explicit depiction of a performance situation.

This essay begins with the description of David's literary activity in 11QPs ${ }^{\mathrm{a}}$ XXVII, a text known as "David's Compositions." As a legendary “author," David in the Psalms scroll assumes elements of the biography of Solomon, another legendary "author." Specifically, the figure of David appropriates the abundant wisdom particular to Solomon's biography in 1 Kings. Because the language of the text places David in implicit competition with Solomon, we may reach beyond the structure of textual frames and further theorize how legendary "authors" functioned in this literary culture.

The discussion is followed by a categorization of biblical titles and textual frames. Here, I intend to demonstrate how these frames situate and organize non-narrative literary material in the medium of text. This categorization will then serve to show how such a study might be used to critically examine literary values. In the case of the titles of Proverbs, one sees how the attributive frames are distinct from textual frames found on ancient Mesopotamian and Egyptian instruction collections. Specifically, the titles of Proverbs attribute its material to a legendary figure from lore: Solomon. However, unlike the frames of ancient Near Eastern instruction collections, the titles of Proverbs do not depict its named legendary figure as the explicit speaker of these instructions. One also observes how the Solomonic frames in Proverbs are distinct from the attributions in Ecclesiastes and Song of Songs. Where in Ecclesiastes and Song of Songs, the attributed figure in the frame becomes a speaking voice in the framed text itself, in Proverbs the attribution is flat: Solomon never clearly emerges as a voice in the text. ${ }^{14}$ Finally, the essay concludes by offering a new view of David's "authorial" claims in 11QPs ${ }^{\mathrm{a}}$ XXVII. The naming of legendary figures like David and Solomon in textual frames more closely approximates our concept of literary genre rather than our concept of author. I argue that these figures function as legendary voices of speech, in varying degrees of narrative or non-narrative framing.

14 I owe this observation and the description of the Solomonic attribution in Proverbs as "flat" in comparison to the attributions in Song of Songs and Ecclesiastes to an anonymous reviewer of this article. See also Thomas M. Bolin, whose recent monograph has drawn out the complex ways Qohelet has been constructed as an authorial voice in the text of Ecclesiastes: Bolin, Ecclesiastes and the Riddle of Authorship (New York: Routledge, 2017). 


\section{David as Solomon}

In The Literary Imagination in Jewish Antiquity, Eva Mroczek demonstrates the many ways in which the Psalms scroll reshapes literary conventions behind and emergent in the text. Using 11QPs ${ }^{\mathrm{a}}$ XXVII, Mroczek's work reconceptualizes our understanding of David as not an illegitimate author of these texts, but rather a rich literary figure, whose many biographical facets are brought in to situate texts within an immanent literary tradition. ${ }^{15}$ The text in 11QPs ${ }^{\mathrm{a}}$ XXVII states, "David the son of Jesse was wise (חכם)," that "Yahweh gave him a discerning spirit (רוח נבונה)," and that he "composed three thousand six hundred psalms." After this specific number of תהלים composed by David, the author of the Psalms scroll gives further accounting of David's compositions in the category of שיר ("song"): three hundred and sixty-four to sing before the altar accompanying the daily burnt-offering, one for each day of the year, fifty-two songs for each Sabbath offering, thirty for New Moon offerings, festivals, and the Day of Atonement, which the author tells us all together add up to four hundred and forty-six, not including an additional four songs to sing on behalf of those "afflicted" or "possessed." This brings the total of שיר to four hundred and fifty, and the author tells us, "The total (that is, of psalms and songs) adds up to four thousand and fifty."

In this text, the figure of David is described with the very phrasing used in 1 Kings 5 to describe Solomon. Already in 1966, William Brownlee's study of the text had made this observation, that 11QPS ${ }^{a}$ XXVII "imitates" the language used in 1 Kgs $5: 9-14 .{ }^{16}$ In 1 Kgs 5:9, the narrator states "God gave Solomon wisdom

15 Mroczek, The Literary Imagination in Jewish Antiquity. See also these ideas in their development from 2008-2015, in Mroczek, "Moses, David, and Scribal Revelation: Preservation and Renewal in Second Temple Jewish Textual Traditions," in G.J. Brooke et al. (eds.), The Significance of Sinai: Traditions about Sinai and Divine Revelation in Judaism and Christianity (Leiden: Brill, 2008), pp. 91-115; Mroczek, "How Not to Build a Temple: Jacob, David, and the Unbuilt Ideal in Ancient Judaism," JSJ 46 (2015), pp. 512-46; Mroczek, "The Hegemony of the Biblical in the Study of Second Temple Jewish Literature," Journal of Ancient Judaism 6 (2015), pp. 2-35; Mroczek, "'David Did Not Ascend into the Heavens' (Acts 2:34): Early Jewish Ascent Traditions and the Myth of Exegesis in the New Testament," Judaïme ancient - Ancient Judaism 3 (2015), pp. 261-94.

16 The classic study is W. Brownlee, "The Significance of 'David's Compositions' [11QPsa ]," RevQ 5 (1966), pp. 569-574; Brownlee already observed that "the passage ... imitates I Kings 5, 9-14." See also J.L. Kugel, "David the Prophet," in J.L. Kugel (ed.), Poetry and Prophecy: The Beginnings of a Literary Tradition (Ithaca: Cornell University Press, 199o), pp. 45-55. More recently, and specifically with respect to David appropriating Solomonic characteristics, see N. Mizrahi, "A Comparison of the List of 'David's Compositions' (11QPsa 27 2-11) to the Characterization of David and Solomon in Kings and Chronicles," Meghillot: Studies in the 
(חכמה) and great discernment (תבונה הרבה מאד)" and in 1 Kgs 5:12, that Solomon "spoke three-thousand 'proverb'-discourses (משלה) and his 'song'-performances (שיר) numbered a thousand and five." Effectively, in the Psalms Scroll, the description of Solomon's intellectual capacity and compositional productivity in 1 Kgs 5:9-14 is interchangeable for David's - 'song' (שיר) remaining a shared category between Solomon and David. In 11QPS ${ }^{\mathrm{a}}$ XXVII, the key Solomonic category of 'proverb'-discourses (משל) is replaced by (תהלים) David's psalms. ${ }^{17}$

There remain other elements of "David's Compositions" that are not a part of Solomon's description in 1 Kgs 5:9-14. While Solomon is described as endowed with wisdom and discernment, David is described with language unique to the biblical description of David and not Solomon..$^{18}$ For example, David is described in the Psalms Scroll as endowed with a discerning spirit רוח רavid is gripped by רוח יהוה (the spirit of Yahweh), and serves as Saul's musical

Dead Sea Scrolls: A Festschrift for Devorah Dimant (Jerusalem: Bialik, 2007), pp. 167-96, where Mizrahi describes the text as transferring characteristics of Solomon to David while also incorporating the tradition of David's "prophetic spirit." See B. Strawn, "David as One of the 'Perfect of (the) Way': On the Provenience of 'David's Compositions' (and ${ }_{11 Q P s}{ }^{a}$ as a Whole?)," RevQ 24.4 (2010): 607-626. And see, most recently, Mroczek, The Literary Imagination in Jewish Antiquity, pp. 51-85, where Mroczek significantly integrates the notion of a character's literary biography with their role in the practice of attribution. Cogan claims that the two literary categories named in 1 Kgs 5:12 "represent two major categories of ancient poetic composition" (Cogan, 1 Kings [New Haven: Yale University Press, 2001], p. 222). I would temper this assertion by adding that this particular biblical narrative claims שיר משל and be major categories of literary activity. However, this particular claim does not necessarily reflect normative ancient categorizations. The classification is as much an ancient scholarly construct as Aristotle's literary classifications. Unlike the sparse title in Prov. 10:1 (משלי שלמה), the title in Prov. 1:1 indicates Solomon's parentage. In Jewish reception, the title in Prov. 1:1 is understood to explicitly trace the transmission of wisdom from father (David) to son (Solomon). See Moses Qimhi's commentary on Proverbs, Perushim lesefer mishle leveyt Qimhi (ed. and trans. Frank Talmage (Jerusalem: Magnes, 1990). Fox cites Qimhi's commentary and points out the parallel of ancient Near Eastern instruction collection frames which also indicate the lineage of the instructor (Fox, Proverbs 1-9, p. 55).

19 The translation of Biblical Hebrew רוח as "spirit" without comment is problematic, theologically charged, and may obscure significant dimensions of the term and how it acts upon a body. However, such a discussion is outside of the scope of the present essay, and is used here as a placeholder pending a more precise translation. See I.E. Lilly, "Rûah Embodied - Job's Internal Disease from the Perspective of Mesopotamian Medicine," in A. Weissenrieder (ed.), Borders: Terminologies, Ideologies, and Performances (Tübingen: Mohr Siebeck, 2016), pp. 323-36. 
therapist. The creative products of David's divine spirit bring relief to Saul's own רוח רע, his "foul temper." “David's Compositions," as Mroczek explains, "draws on and develops a range of older traditions about David's personality" - traditions attested within and outside of the Hebrew Bible - "and foreshadows later traditions in which David becomes a heavenly figure singing the cosmic liturgy" 20

In contrast to David's discerning spirit (רוח נבונה) in "David's Compositions," Solomon in 1 Kgs 5:9 is given great discernment (תבונה הרבה מאד). In 1 Kings 5, Solomon's "great discernment" is linked to his "breadth of mind" (רחרב לבר), which is further described with the imagery of the vastness of the sands on the seashore (כחול אשר על-שפת הים). The imagery and the description together impart a sense of the "uncountable numbers," to borrow Cogan's words. ${ }^{21}$ This description of Solomon's intellectual capacity coheres well with his described achievements of many thousands of literary compositions in 1 Kgs 5:12. This is not the case with the application of Solomon's quality of abundant literary composition to David, where the description of his attributes does not anticipate the literary accounting that follows. The description of David in "David's Compositions" as "luminous like the light of the sun, and a scribe, and discerning, and perfect in all his paths before God and men [sic]" does not conjure a similar coherent image of a figure of abundant literary production. ${ }^{22}$

Using a tradition of David as gripped by a divine ("spirit"), "David's Compositions" has incorporated elements of Solomon's biography that were not part of the David tradition - wisdom and discernment. More to the point, while David in the biblical narrative tradition is a frequent performer of poetry and song, his compositions are never enumerated. It is Solomon, rather, who is described as a prolific composer, with vast numbers assigned to these compositions: three thousand proverbs and one thousand and five songs (1 Kgs 5:12). The description of David's compositional activity in the Psalms scroll grafts characteristics of Solomon onto David, appropriating a tradition of Solomon's prolific composition of משל ("proverbs" or "instruction") for David's prolific תהלים ("praises"), exceeding Solomon's three thousand to the tune of three thousand six hundred. Even the total number of David's literary abundance exceeds that of the biblical Solomon, with Solomon clocking in at

\footnotetext{
$20 \quad$ Mroczek, Literary Imagination, p. 72.

21 Cogan, 1 Kings, p. 221. See also Mroczek's discussion of "qualitative numbers" in this text and the enumeration of texts in Jewish antiquity (Mroczek, Literary Imagination, pp. 15683).

Translation from Mroczek, Literary Imagination, p. 71.
} 
four thousand and five, but David here in "David's Compositions" at four thousand and fifty.

The recasting of Solomon's divine gift of wisdom and discernment for David in ${ }_{11 Q P S}{ }^{a}$ XXVII has already been treated extensively in previous scholarship, and most felicitously in Mroczek's work, where she recasts the literary work of attribution - Davidic or otherwise - "as biography, not bibliography."23 Here I wish to inquire, specifically with respect to the poetics of attribution in the biblical literary tradition, what it might mean within the biblical literary tradition for a legendary "author" like David to assume the characteristics of another legendary "author." Why has the David of the Psalms scroll appropriated characteristics and activities traditionally ascribed to Solomon? What does such a move mean, literarily, and what can this tell us about how legendary figures like David and Solomon functioned in the practice of attribution?

The following categorization of textual frames and case study of the Solomonic titles in the book of Proverbs will show how a study of textual frames might help recover an ancient poetics of attribution.

\section{Biblical Textual Frames: Towards a Categorization}

A categorization of textual frames follows necessarily from a description of titles and how these titles function to frame text. In the biblical literary materials, titles are generally not found on narratives. ${ }^{24}$ Narrative relies on the

23 Mroczek, Literary Imagination, p. 119.

24 Compare, for example, to a few titles found on the first line of Ugaritic narrative tablets, such as $l b$ ( "Belonging to (the) Baal (series)" (KTU 1.6.1.1), [lk]rt and [l]krt, "Belonging to (the) Kirta (series)" (KTU 1.14.1.1 and 1.16.1.1), and $[l] a q[h] t$, "Belonging to (the) Aqhat (series)" (KTU 1.19.1.1). These titles, however, seem to function more as library or bibliographic markings (identifying the series to which the tablet belongs) than literary frames. Though structurally such a title may appear identical to non-narrative titles such as ascriptions לדוד on Psalms - a simple / prepositional phrase identifying a legendary character - in the case of the Ugaritic narratives, the named individual is the protagonist of the tale. In the case of the biblical titles, like לשלמה לדוד, the named individual is, in fact, a figure external to the world of the text. Colophons identifying Ilimilku as, variously interpreted, the scribe or author of the texts are functionally closer to biblical attributions, in that both framing texts - לדוד and the colophons like that of KTU 1.6.7.54-58 identifying Ilimilku as "scribe" (spr) and in a tradition of literary transmission - refer to named individuals who inhabit a world outside the composition the title or colophon frames. As discussed in this paper, attributions such as those attested in Song 1:1 and Eccl. 1:1 complicate an external framing of the text, since the legendary figure named in these titles also functions as a character in the text. See D. Pardee, "L'autorité littéraire au XIII 
mechanism of narrated time and the voice of a narrator to frame and structure its material. ${ }^{25}$ By contrast, non-narrative material, like poetry, prophetic speeches, and instructions, relies on a greater variety of mechanisms to present itself in a textual medium. For example, narratives like the book of Ruth utilize no framing outside the narrating voice. The narrative opens with in a third-person narrative voice, which situates events in time: ויהי בימי שפט השפטים ("in the days when the judges judged"). The narrative then moves to more closely focus on the main characters of the story. Similarly, Esther opens, ויהי בימי אחשורוש ("in the days of Ahasuerus"). Yet other literary materials songs of lament, songs of praise, speeches - do not configure events in time. ${ }^{26}$

Steven Weitzman, in Song and Story in Biblical Narrative, describes the presentation of these other, non-chronologically organized texts as "inserted" into their narrative frame. ${ }^{27}$ Weitzman interprets this compositional practice as reflecting a particular literary value, one the biblical authors articulated through configuring the text in this way. This essay aims towards a fuller description of the phenomenon of poetry and speech embedded in their frames by examining and categorizing not the embedded texts, but rather the structure of the frames themselves. In this study, the presentation of these non-narrative materials - songs, laments, and other types of speeches - are understood to be "staged" performances in a narrative within the text. That is to say, these poems are situated within an extended narrative context and staged within a narra-

siècle av. J.-C.? 'Ilîmilku d'Ougarit: scribe/auteur?," in M. Gorea and M. Tardieu (eds.), Autorité des auteurs antiques: entre anonymat, masque et authenticité (Brepolis, 2014), pp. 35-57, esp. p. 47 .

25 According to Shlomith Rimmon-Kenan, narrative stages speech through diegesis. Since texts consist of language, which signifies and does not imitate, the closest a text can come to a true imitation of the action it represents is the representation of speech performance. This representation of character speech is staged within the narrator's telling. See S. Rimmon-Kenan, Narrative Fiction (New York: Routledge, 1989), p. 111.

26 The distinction between textual narrative and represented speech performance is articulated differently by Robert Kawashima, who draws on the distinction made by Benveniste between histoire and discours. According to Kawashima, the distinctive tellings of Judges 4 and 5 can be described, respectively, as either the telling of an event fixed in the past (narrative) or the telling of an event through live performance (oral literature), which expresses past events to the present of the audience. See R. Kawashima Biblical Narrative and the Death of the Rhapsode (Bloomington: Indiana University Press, 2004), pp. 37, 168.

S. Weitzman, Song and Story in Biblical Narrative (Bloomington: Indiana University Press, 1997), p. 4. 
tive of performance: a character, in the fictional space of the narrative, gives voice to these songs and speeches. ${ }^{28}$

I have discerned three basic types of textual frames for non-narrative materials: (1) an extended narrative framing speech; (2) a minimal narrative framing speech, usually of a single verb of performance or transmission with few other contextual markers; and (3) a non-narrative frame consisting of a genre term and a named individual, usually called a "title." The categories outlined here are, for the most part, heuristic. The categories identify similarities and distinctions between various frames for performed speech. A frame that might count as an "extended" narrative is surely on a spectrum, and here I use such a category to collect those I have identified as full narrations of performance situations. These narrations provide a represented context for the framed speech. Likewise, a frame that might count as a "minimal" narrative is also generically determined (or rather, book-divisionally determined). Such narrative frames are found exclusively in the Latter Prophets, whose non-narrative speeches, unlike biblical law, are not staged within an extended narrative history. The categorization of textual frames presented here identifies a shared element across frame types: the attribution of the framed text to a named individual. Whether or not the moment of performance or its transmission is narrated, the frame attributes the speech to a named individual whose biography (inside or outside the frame) provides a context for the framed speech.

The first type of frame is an extended narrative that stages a speech performance. This type of frame narrates a context for speech that may or may not be designated by a generic term. These narratives can be more expansive and therefore experience greater prominence in their reception than the actual text the narrative intends to frame. Such is the case for the narrative staging the speeches in Job or the narrative of Ahiqar framing the proverbs. By contrast, framing narratives can be less extensive. Further, the framing narrative can be embedded within larger narratives, like the משל-performances of Balaam in the context of Numbers 22-24. The narrative staging of the performance provides a situational context for the poem's or speech's interpretation within the literary tradition. A text's frame, narrative or not, contextualizes a work for a reader, bridges the world of the reader and the inner world of the

28 Similarly, Richard Martin reconfigures $\mu \hat{\vartheta} \theta 0 \varsigma$ in Homeric poetry as a speech act, and urges scholars to focus their efforts on reconstructing the "poetics of Homeric speechmaking," that is, the textual framing and representation of speech. See R. Martin, The Language of Heroes: Speech and Performance in the Iliad (Ithaca: Cornell University Press, 1989), p. 46. 


\begin{tabular}{|c|c|c|c|c|}
\hline & Genre & Named speaker & $\begin{array}{l}\text { Narrative of } \\
\text { performance }\end{array}$ & Narrative context \\
\hline 2 Sam. 1:17 & $\begin{array}{l}\text { קינה } \\
\text { lament }\end{array}$ & David & $\begin{array}{l}\text { he performed } \\
\text { (cognate verb) this } \\
\text { lament over Saul } \\
\text { and his son } \\
\text { Jonathan }\end{array}$ & $\begin{array}{l}\text { death of Saul and } \\
\text { Jonathan }\end{array}$ \\
\hline Judg. 14:12-14 & $\begin{array}{l}\text { Riddle } \\
\text { Rידה }\end{array}$ & Samson & $\begin{array}{l}\text { let me perform for } \\
\text { you } \\
\text { (cognate verb) a } \\
\text { riddle... }\end{array}$ & $\begin{array}{l}\text { Samson at a feast } \\
\text { in Timnah }\end{array}$ \\
\hline Num. 23:7 & $\begin{array}{l}\text { משל } \\
\text { Teaching }\end{array}$ & Balaam & $\begin{array}{l}\text { he spoke out his } \\
\text { teaching }\end{array}$ & $\begin{array}{l}\text { Balaam responds } \\
\text { to King Balak's } \\
\text { requests }\end{array}$ \\
\hline Exod. 15:1 & $\begin{array}{l}\text { שירה } \\
\text { Song }\end{array}$ & $\begin{array}{l}\text { Moses and the } \\
\text { Israelites }\end{array}$ & $\begin{array}{l}\text { they performed } \\
\text { (cognate verb) this } \\
\text { song to Yahweh }\end{array}$ & $\begin{array}{l}\text { victory at the sea } \\
\text { over Egyptians }\end{array}$ \\
\hline
\end{tabular}

FIGURE 1 Frame Type 1: Extended narrative context.

text, and may narrow its generic and interpretive possibilities. ${ }^{29}$ Rimmon-Kenan likewise speaks of the function of the frame in her discussion of the "primacy effect," "the crucial influence of initial information in the process of perception."30

The table in Figure 1 provides four examples of such narrative frames with explicit genre designations, such as חידה or. In these cases, the genre designations figure in the narrative of performance, usually with the cognate verb, and in all cases the speaker named.

A second type of narrative frame presents non-narrative material - prophetic speeches, mainly - within a narrative of speech performance or transmission. What distinguishes this type of frame from the preceding is that there is usually only a single verb indicating the performance or transmission of the

29 See discussion of Genette's paratextual theory below. Similarly, in a study of Psalm 23, Dennis Pardee discusses how the psalm's initial framing features "are strong enough that the listener will give preference to them in his registering what the formal structure of this work is and will reject the 'non-poetic' structures as indicators of prose." That is, Pardee argues that even the prosody of a frame, in lieu of other generic/modal markers, can serve to determine the text's categorization as 'poetry.' See D. Pardee, "Structure and Meaning in Hebrew Poetry: The Example of Psalm 23," Maarav 5-6 (Spring, 1990), pp. 239-80 (270-71). 
subsequent non-narrative material by the named performer. Sometimes this frame will situate the performance in time (indicated on the chart as the "temporal context"), and other times it will not.

David Freedman, in his study of the headings of prophetic books, understood the two types of headings, דברי עמוס ... אשר חזה השה (the words of Amos ... which he prophesied") and דבר-יהוה אשר היה אל-הושע ("the word of Yahweh came to Hosea)," to possess a unified structure consisting of two elements: (1) "the experience of the prophet or the core of divine revelation"; and (2) "the [named] prophet himself [sic], or the source of revelation, Yahweh," followed by the verbs היה or, "used to qualify the initial phrase."31 By contrast to Freedman's categorization, I have distinguished between these two types, in that, even though they are both minimal narrative frames, they differently stage the text. The first, דברי עמוס ... אשר חזה ("the words of Amos ... which he prophesied") is a narrative of performance, and the second, דבר-יהוה אשר ("the word of Yahweh came to Hosea") is a narrative of transmission. Examples are given of these two types of minimal narratives in Figures 2 and 3, respectively. While Freedman understood these titles to be structurally identical with varying options within this single structure, his study neglected to account for the fact that these are functionally two types of frames. ${ }^{32}$ While both types have a near identical grammatical structure, they can be distinguished by the type of minimal narrative in the title. One type authorizes the text through depicting the moment of the speaker's performance. The second authorizes the text by accounting for the moment of the text's transmission from the deity to the prophetic speaker.

The examples provided in the figures below are not meant to be comprehensive or definitive. The prophetic collections are framed in varied and complex ways, often with multiple frames embedding speeches and frequent shifts between first and third person voice. These two types of "minimal narratives" are merely distinguished here in order to show that not all frames simply stage a performance, but that some frames describe a transmission of speech - often the transmission of a prophetic message. Seminary Studies 25.1 (Spring 1987): pp. 9-26 (9-10, emphasis mine). accordance with a standard form and formula, but ... were modified to accommodate the differences in time and place of the individual prophets" (Freedman, "Headings," p. 25). I am making no such claim. Rather, I seek to account for the different types of frames used, and categorize their variations according to certain pragmatic similarities in order to explain how the frames function differently for staging non-narrative material. 


\begin{tabular}{|c|c|c|c|c|}
\hline & Genre & Named speaker & $\begin{array}{l}\text { Narrative of } \\
\text { performance }\end{array}$ & $\begin{array}{l}\text { Temporal } \\
\text { context }\end{array}$ \\
\hline Isa. $1: 1$ & $\begin{array}{l}\text { חזון } \\
\text { vision of }\end{array}$ & Isaiah & he prophesied (חזה) & yes \\
\hline Amos 1:1 & $\begin{array}{l}\text { דברי } \\
\text { words of }\end{array}$ & Amos & $\begin{array}{l}\text { he prophesied } \\
\text { (ח) }\end{array}$ & yes \\
\hline Hab. 1:1 & $\begin{array}{l}\text { המשא pronouncement } \\
\text { prounction }\end{array}$ & Habakkuk & $\begin{array}{l}\text { he prophesied } \\
\text { (חזה) }\end{array}$ & no \\
\hline
\end{tabular}

FIGURE 2 Frame Type 2a:Minimal narrative of performance.

\begin{tabular}{|c|c|c|c|}
\hline & Genre & Narrative of transmission & $\begin{array}{l}\text { Temporal } \\
\text { context }\end{array}$ \\
\hline Jer. $1: 2$ & ward-of-Yahweh דבר-יהוה & came to him (Jeremiah) & yes \\
\hline Ezek. 1:3 & ward-of-Yahweh דבר-יהוה & came to Ezekiel & yes \\
\hline Hos. 1:1 & ward-of-Yahweh דבר-יהוה woh & came to Hosea & yes \\
\hline Joel 1:1 & word-of-Yahweh דבר-יהוה & came to Joel & no \\
\hline Mic. 1:1a & ward-of-Yahweh דבר-יהוה & came to Micah & yes \\
\hline Zeph. 1:1 & ward-of-Yahweh דבר-יהוה & came to Zephaniah & yes \\
\hline Jon. 1:1 & ward-of-Yahweh דבר-יהוה & came to Jonah & no \\
\hline Hag. 1:1 & ward-of-Yahweh דבר-יהוה woh & came by Haggai & yes \\
\hline Zech. 1:1 & ward-of-Yahweh דבר-יהוה & came to Zechariah & yes \\
\hline
\end{tabular}

FIGURE 3 Frame Type 2b: Minimal narrative of transmission.

Take for example the frame for the book of Isaiah in its present form:

$$
\text { חזון ישעיהו בן אמוץ אשר חזה על יהודה וירושלם בימי עזיהו יותם אחז יחזקיהו }
$$

The vision of Isaiah son of Amoz who prophesied concerning Judah and Jerusalem in the reigns of Uzziah, Jotham, Ahaz, and Hezekiah, kings of Judah.

This frame presents a minimal narrative context of the speech performance that follows (שמעו שמים והאזיני ארץ ["listen, O Heavens, give ear, O Earth"). This narrative context provides only the details of the performance of the sion") in a general range of dates. Nevertheless, the narrative frame stages the speech in this context of performance, pointing outward to the world to situate 
what would otherwise be decontextualized, atemporal utterances. The naming of the titular figure in the title in Isa. 1:1, as Peter Ackroyd argued in his now classic study, marks off the book as a kind of Isaianic discourse. ${ }^{33}$ In Ackroyd's words, titles like those in 1:1, as well as those in 2:1, whose form and language closely mimic the title in 1:1, operate within the collection and at its boundaries in "a process of claiming a particular kind of status for the prophet and a particular kind of authority for [the] collection as a whole." ${ }^{34}$

The frame type listed in the table above (Fig. 3) is a variation of the frame type in Figure 2. This frame presents a narrative context in a formulaic manner. Instead of a narrative of performance, here we find a narrative of transmission. Here the genre is not the "vision of so-and-so," but דבר-יהוה ("the word of Yahweh"). Rather than giving a minimal depiction of a moment of speech performance, the transmission-type narrative describes the passage of the speech from the deity to the prophetic speaker. One should keep in mind that the categorizations presented here are meant to highlight differences between frames, but one should also take note that many of the frames, particularly those found in the prophetic collections, are not as simple as either one type or another. For example, while I have given the title in Jer. 1:2 as an example of frame type $2 b$ (Fig. 3), a minimal narrative of transmission, one easily notices that the preceding element of the frame in Jer. 1:1 without its continuation in v.2 looks like a non-narrative title:

\section{דברי ירמיהו בן-חלקיהו מן-הכהנים אשר בארץ בנימין בענתות}

The words of Jeremiah son of Hilkiah, of the priests who were in Anathot in the land of Benjamin.

This frame could be categorized as a simple, non-narrative title like that of Prov. 1:1. Frames often are multiplied, where one type is attached to another. This can occur as single, grammatically coherent sentences as in Jer. 1:1-2. Or, this can occur in successive frames as in Balaam's משל in Num. 24:3-9, where the first frame v.3a presents a minimal narrative of performance (וישא משלו) [יויאמר ["He spoke out his instruction"]) and the second frame in v.3b presents a simple title (נאם בלעם בנו בער [“Utterance of Balaam son of Beor”]).

Complex frames which combine a narrative of speech performance and transmission might be compared to the opening of Hesiod's Theogony. ${ }^{35}$ There,

33 P. Ackroyd, "Isaiah I-XII: Presentation of a Prophet," in John Emerton (ed.), Congress Volume: Göttingen 1977 (VTSupp, 29; Leiden: Brill, 1978), pp. 16-48.

34 Ackroyd, "Isaiah I-XII," p. 35.

35 The comparison of the framing of biblical prophetic speech and wisdom literature to Hesiod is not an arbitrary one, nor am I the first to propose such a comparison. Toy, in his 
a description of speech performance, "Let us begin," is preceded by a narrative of transmission in lines 22-24 of the $\mu \hat{v} \theta 0 \varsigma$ (the speech) from the Muses to Hesiod, who is the identified speaker of the words following the proem: ${ }^{36}$

The ones who once instructed Hesiod beautiful song while he was tending sheep under holy Helicon. The goddesses first spoke the following $\mu \hat{v} \theta$ os to me ... (Hesiod, Theogony 22-24)

This frame interestingly features a shift in voice, moving within the frame itself from the third-person narrator, who names Hesiod as the speaker, to the speaker himself in the first person voice. This is one strategy to invite the readers over the threshold of the textual frame into the performance arena of the speech itself. ${ }^{37}$ Along these lines, López-Ruiz observes, "[F]or the early Greek poet, there were not many options when opening a poem"; one could invoke the Muses, that is, identify the transmission of the poem to the speaker. ${ }^{38} \mathrm{Al}-$ ternately, one could indicate its performance, using a verb of singing, often in the first person, "I will sing," or "Let me sing." ${ }^{39}$ More sharply, however, one might note that just as biblical frames name legendary individuals like Solomon, a similar phenomenon is observed in the attribution of ancient Greek texts to Hesiod. Hesiod is a famed speaker whose biographical persona - and perhaps even his very name ${ }^{40}$ - imaginatively stages the discourse in a

1899 commentary of Proverbs, compares Proverbs as didactic poetry to Hesiod's Theogony and Works and Days. See C.H. Toy, Proverbs (New York: T\&T Clark, 200o), p. xxxvi.

36 Martin, The Language of Heroes, p. 46.

37 See similar arguments for Hesiod's Works and Days by Ruth Scodel, who invokes Foley's terminology for this transition as the entry into the "performance arena." See R. Scodel, "Works and Days as Performance," in Elizabeth Minchin (ed.), Orality, Literacy, and Performance (Leiden: Brill, 2011), pp. 111-26. See also J. Foley, The Singer of Tales in Performance (Bloomington: Indiana University Press, 1995), pp. 47-49.

38 C. López-Ruiz, When the Gods were Born (Cambridge: Harvard University Press, 2010), pp. 51-52.

39 López-Ruiz, When the Gods were Born, pp. 51-52. Mark Smith has recently discussed the use of voicing and voice shifts in the framing of poetic texts. With respect to first person frames, he explains, "The first person lines provide a rhetorical foregrounding that represents a personal excitement for past events ... [to] move the audience." See M. Smith, Poetic Heroes: Literary Commemorations of Warriors and Warrior Culture in the Early Biblical World (Grand Rapids: Eerdmans, 2014), pp. 259-60.

40 In the proem of the Theogony, Hesiod is identified by name by an anonymous frame speaker, and then, in his own voice, Hesiod claims that the Muses had "breathed a divine voice into me" (Theogony 31). Hesiod describes Muses as having sent forth their voice four times (Theogony 10, 43, 65, 67). This was sufficiently suggestive that a few scholars ety- 
moment of speech performance and transmission. It is therefore unsurprising that, like Solomon, Hesiod's name attracted later compositions by other anonymous authors writing under his aegis, such as The Great Ehoiai, Precepts of Chiron, Bird Omens, and others. ${ }^{41}$ We will return to Solomon's name shortly. For the moment we observe that a narrative of performance and transmission functions to stage the speech and ground it in a temporal and geographical context. Importantly, however, the identification of the named individual classifies the speech-type within the literary culture. This seems most evident with figures like David or Solomon, whose names become attached to particular types of speech. These attributions engage elements of these legendary figures' biographies, such as David's expertise in music and exorcism, or more pointedly, Solomon's success not only in wisdom but the abundance it promises.

Returning to the biblical literary materials, we identify a third type of frame (see Fig. 4). This third frame type appears to depart pragmatically from the first two types, since it does not take the form of a narrative. This frame is neither a narrative of performance nor transmission, but simply a title that indicates the genre and named individual - the sort of title framing most of the Psalms, Ecclesiastes, Song of Songs, and the Solomonic titles of Proverbs. Such a nonnarrative framing for Psalms, for example, might not seem unusual if we compare these titles to the similarly spare, non-narrative headings for Pindar's Odes. Those headings mark an early reception of Pindar, and as Alexandrian library markings, they appear to classify the poems, placing them in the context of their textual medium. The headings do not explicitly contextualize the poem in a performance as do the narrative frames we have described above. ${ }^{42}$ They refer to the patrons of the poems. The scope of the present essay does not permit an examination between the library markings of Pindar's poems and

mologized Hesiod's own name as "He who emits the voice" or "He who emits song." See G. Most, Hesiod: Theogony, Works and Days, Testimonia (Cambridge: Harvard University Press, 2006), p. xv. See proposal of G. Nagy in "Hesiod and the Ancient Biographical Traditions," in F. Montanari et al. (eds.), The Brill Companion to Hesiod (Leiden: Brill, 2009), p. 286.

41 See Pausanias, Description of Greece 9.31.4-5. This second century catalogue of Hesiod's compositions first speaks of how the Boeotians (unlike other groups) only attribute Works and Days to Hesiod, nothing else, even taking from Hesiod the introductory frame to the Muses. The catalogue then relates parts of Hesiod's biography to the attribution of other works to him, for example, "These latter [epic poems] also say that Hesiod was taught the mantic art by the Acharnians; and in fact there is a poem on soothsaying." University Press, 2015), pp. 53-63. 


\begin{tabular}{|c|c|c|}
\hline & Genre & Named Individual \\
\hline $\begin{array}{l}\text { Ps. 15:1a } \\
\text { (and others) }\end{array}$ & $\begin{array}{l}\text { מזמור } \\
\text { psalm }\end{array}$ & $\begin{array}{l}\text { לדוד } \\
\text { of David }\end{array}$ \\
\hline Song 1:1 & $\begin{array}{l}\text { שיר השירים } \\
\text { song of songs }\end{array}$ & $\begin{array}{l}\text { אשר לשלמה } \\
\text { which is Solomon's }\end{array}$ \\
\hline Eccl. 1:1 & $\begin{array}{l}\text { דברי } \\
\text { words }\end{array}$ & $\begin{array}{l}\text { קהלת בן-דוד מלך בירושלם } \\
\text { of Qoheleth, son of David, } \\
\text { king in Jerusalem }\end{array}$ \\
\hline Prov. 1:1 & $\begin{array}{l}\text { משלי } \\
\text { proverbs }\end{array}$ & $\begin{array}{l}\text { שלמה בץ-דוד מלך ישראל } \\
\text { of Solomon, son of David, } \\
\text { king of Israel }\end{array}$ \\
\hline Obad. 1 & $\begin{array}{l}\text { חזון } \\
\text { prophecy }\end{array}$ & $\begin{array}{l}\text { עבדיה } \\
\text { Obadiah }\end{array}$ \\
\hline Nah. 1:1 & $\begin{array}{l}\text { משא נינוה ספר חזון } \\
\text { pronouncement on Nineveh, the } \\
\text { record of the prophecy }\end{array}$ & $\begin{array}{l}\text { נחום האלקשי } \\
\text { Nahum the Elkoshite }\end{array}$ \\
\hline
\end{tabular}

FIGURE 4 Frame Type 3: Genre term + named individual; no narrative of performance or transmission.

the titles on Psalms, though such an investigation would be valuable for further contextualizing the framing of Psalms. Generically, structurally, and anthologically, the psalms seem to be more amenable to a comparison to the textual framing of Pindar's compositions than a collection of instructions might. In the first place, both the psalms and odes are self-contained compositions with more or less defined boundaries. These boundaries are reinforced by their titles.

\section{Textual Frames in the Instruction Genre}

By contrast, instruction collections, like the Sumerian Instructions of Shuruppak, the Aramaic Instructions of Ahiqar, or the Egyptian Instructions of Ptahhotep, frequently do not follow an immediately discernible structure beyond their typical narrative frame. Though they are framed as speech, their structure does not conform to what we might recognize as a coherently structured speech or an organized lecture. The instructions themselves often do not maintain consistent themes or follow a logical sequence. Instructions on proper sexual conduct are mixed in with business or farming advice, principles of rhetoric, and theological statements. Voicing is also inconsistent. One finds instructions addressed in the second person to the fictional audience - usually to 
the son or student of the named legendary speaker - followed immediately by third-person generalizations of behavior and the world that give no indication of time or place, much less any context of speech performance. Save occasional calls to the audience, "My son, listen to my words," the instructional material within the speech-performance frame offers few hints that the text is to be understood as the spoken instructions of the legendary speaker. And unlike the prosodic or structural features of self-contained compositions like psalms - whose coherence and often-unified content can independently identify it generically, with or without a framing title - instructions and proverbs are by definition decontextualized and atemporal discourses. Instruction collections thus depend upon a narrative frame of speech-performance or transmission to define them, generically, as instructions. It is for this reason that the sparse, non-narrative Solomonic titles of Proverbs are so striking.

Instruction is a type of speech performance in the literary worlds out of which these texts emerged. Of course, the instruction texts we encounter are written, and I do not intend to claim evidence for the oral origins of these texts. Rather, I intend to draw attention to how the framing of these texts fictionally represent a moment and situation of oral performance. This performance frame contextualizes and generically marks the advice that follows. In the case of instruction texts, the narrative frame functions significantly to give context to the decontextualized utterances. Otherwise, this same type of material could be understood perhaps as law ${ }^{43}$ or omen, ${ }^{44}$ or some other literary type. The frame narrows its interpretive possibilities. Looking at over a dozen Sumerian, Akkadian, Egyptian, Aramaic, and Greek instruction collections, dating from the third millennium вСE to the end of the first millennium вСE - all of the texts whose opening lines were reasonably preserved - one observes that

43 For a study on the relationship between the biblical genres of wisdom and law (though a different approach from the pragmatic one employed in the present work), see B. Jackson, Wisdom Laws (Oxford: Oxford University Press, 2006).

44 Notably, one of the few apparent Mesopotamian instruction collections that do not bear a narrative frame of performance and/or transmission is the Akkadian text, Advice to a Prince, for which we have only one copy from Ashurbanipal's library, dating to the Late Assyrian period. The text has been frequently compared to omens rather than instructions, largely for its initial structure, šarru ana dīni lā iqûl ("if a king does not heed justice"). See W.G. Lambert, Babylonian Wisdom Literature (Winona Lake: Eisenbrauns, 1996), pp. 110-15. Thus we have in the Advice to a Prince an exception to instruction collection frames that seems to prove the rule: initial framing largely determines the reader's identification of the genre. 
with only one notable exception, these collections are all framed by a narrative of transmission, a narrative of speech performance, or both. ${ }^{45}$

Briefly, we will focus on one example of the particular kind of narrative frame to be found on instruction texts by looking at the prologue to the Sumerian Instructions of Shuruppak, and then we will compare this frame to the Solomonic title framing Proverbs. As discussed in an earlier publication, the prologue of the Instructions of Shuruppak demonstrates how the brief narrative of speech performance serves to identify the words that follow generically as "instructions" and how the narrative gives authority in the form of authenticity and efficacy to the instructions. ${ }^{46}$ The frame claims great antiquity and lineage for the words as well as its efficacy. The efficacy of the words is claimed through attribution to a legendary figure whose wisdom resulted in fantastical rewards. The text begins: ${ }^{47}$

In those days, in those far remote days, in those nights, in those faraway nights, in those years, in those far remote years...

45 For example, the Sumerian Instructions of Shuruppak - dating to the Early Dynastic period, and whose textual tradition continues for over a thousand years - is framed by a narrative of performance and transmission; see following discussion. See also B. Alster, The Instructions of Šuruppak (Copenhagen Studies in Assyriology, 10; Copenhagen: Akademisk Forlag, 1974). LBA Mesopotamian instruction collections, such as Šimâ Milka (the instructions of Šüpê-amè $(i)$, the Ballad of Early Rulers, and Enlil and Namzitarra, all feature some kind of transmission narrative in their frame, and two of the three frame the discourse as speech performance. See Y. Cohen, Wisdom from the Late Bronze Age (Atlanta: Society of Biblical Literature, 2013). The so-called Assyrian Collection, a bilingual MA instruction collection, is framed as speech, a dialogue between an Amorite and his wife. See Lambert, Babylonian Wisdom Literature, p. 230. The Egyptian instruction texts likewise attest narrative frames; for example, the Instruction of Prince Hardjedef, the Instruction of Ptahhotep, the Instruction of Amenemope, and the late Ptolemaic Instruction of Ankhsheshonq all stage their advice in explicit speech performance contexts. See M. Lichtheim, Ancient Egyptian Literature (2 vols.; Berkeley: University of California Press, 1973). Note also that the Aramaic Instructions of Ahiqar, Hesiod's Works and Days, and Pirke Avot all frame their instructions and proverbs with a narrative of performance and transmission. With respect to the literary afterlife of the Instructions of Ahiqar, attention to its vivid and dynamic frame narrative comes to eclipse the instructions themselves.

46 Vayntrub, "The Book of Proverbs and the Idea of Ancient Israelite Education," p. 11. As I argued there, the narrative frames of instructions "offer an ideal or model performance situation that socially locate [the] 'instructions' and encourage a particular reception." Lines 1-5. Translation from Alster, The Instructions of Šuruppak. 
The words continue with a specification of what moment from the deep past is narrated here in the frame:

at that time the wise one, who knew how to speak in elaborate words, lived in the land, Shuruppak, the wise one, who knew how to speak in elaborate words, lived in the land.

The instructions, as situated by the frame, are directed to the speaker's son, Ziusudra: "Shuruppak, the son of Ubar-Tutu gave instructions to his son Ziusudra." 48 This is the narrated moment of performance, where Shuruppak, the speaker, directs his instruction to his son. The significant character in this particular frame text is not the speaker Shuruppak, but in fact the one receiving the wisdom, his son Ziusudra. In the Sumerian flood account, Ziusudra had great wisdom. ${ }^{49}$ The narrative frame therefore appeals to a promise shared by different instruction collections, namely, that words of wisdom are life-saving. Wise speech has the capacity to not only save one from immediate mortal danger but also to soften one's inevitable mortality, either through abundance of wealth, abundance of days, or even an abundance of heirs. The relationship between Shuruppak (the individual transmitting the knowledge) and Ziusudra (the individual on the receiving end) implicitly attests to the quality and effectiveness of the instructions themselves. This is because the individual who received these instructions attained the unattainable: immortality. ${ }^{50}$

The Instructions of Shuruppak is but a single example of how ancient Near Eastern instruction collections are framed by a self-contained narrative of the moment of performance. While these texts engage broader literary traditions and identify individuals known from lore, the frames of these instruction collections do not depend on narrative biography external to the text to give the work a context of speech performance. By contrast, the Solomonic titles in

48 Lines 1-5. Translation from Alster, The Instructions of Šuruppak.

49 Lambert goes so far as to claim that the named speaker is a convenient invention for the frame, since Shuruppak does not appear in the Sumerian King list as an antediluvian king (Babylonian Wisdom Literature, pp.93-94). Whether or not this is the case, it is significant that the addressee and not the speaker of the frame is the widely known figure from lore. As I argued in "The Book of Proverbs and the Idea of Ancient Israelite Education," "Ziusudra's wisdom" was so great that it "allowed him the immortality of the gods" (p. 11).

50 Likewise, I claimed in "The Book of Proverbs and the Idea of Ancient Israelite Education," that the frame of the Instructions of Shuruppak constitutes "a testament to the effectiveness of the instructions: the words ensure the survival and success of one generation to reach the instruction of the subsequent generation" (p. 11). 
Proverbs depend on an outside narrative biography of Solomon to indicate that what we are reading links up to the tradition of Solomon's vast capacity for wisdom and the abundance this wisdom brings. In the literary tradition of 1 Kings 5 , this vast capacity is demonstrated by Solomon's prolific composition of משל. The Solomonic titles of Proverbs draw on the external biography of a legendary figure to authorize a collection of instructions and to identify its literary form.

What is interesting, then, about the biblical frames of the third type (Fig. 4, above) is that while the titles name legendary speakers, they notably lack a narrated instance of speaking. On the one hand, we observe that all three of these types of textual frames serve the same purpose. Titles, as textual frames, provide a context for the literary material they present. They could be understood in Genette's formulation as paratexts, or thresholds. ${ }^{51}$ The paratext, like a frame on a work of art, "surround[s the text] and extend[s] it, precisely in order to present it." ${ }^{2}$ The titles and textual frames - both narrative and non-narrative - establish boundaries between the external world and the internal world of the text. These frames engage tradition and conceptions of literary categories - genres - to condition the reader's experience of the text. The frame, as a paratext, provides a kind of interpretive key for the text it contains, and has unique capacity to indicate the genre, the literary values and conventions of the text. Unlike explicit narrative frames, non-narrative titles rely on the reader's knowledge of a broader literary tradition to fill in the gaps.

The minimal nature of titles like משלי שלמה ("Proverbs of Solomon") depends upon the knowledge of the ancient audience encountering the text to make the connection between the title, the internal world of the text, and the external world of the literary tradition. A reader inculcated in the biblical literary tradition would associate the attribution of משל of Solomon with his reputation for vastness and abundance - particularly with his capacity for speech, but also with his legendary excess in general: Solomon's abundance in words, wealth, and women. As Weitzman has aptly noted, "Solomon seems to do everything in multiples of thousands." ${ }^{n 3}$ There are, of course, other figures in

$51 \quad$ G. Genette, Paratexts: Thresholds of Interpretation (New York: Cambridge University Press, 1997). See also Genette and M. Maclean, "Introduction to the Paratext," New Literary History 22.2 (1991), pp. 261-72 (268).

Genette, Paratexts, p. 2. Sympathetic to Rimmon-Kenan's previously discussed "primacy effect," Genette quotes Philippe Lejeune in explaining how the paratext can determine an interpretation of the entire text, "a fringe of the printed text in which reality controls one's whole reading of the text."

S. Weitzman, Solomon: The Lure of Wisdom (New Haven: Yale University Press, 2011), pp. 150-51. 
the titles of other sections of Proverbs, some of them even figures who speak from the titles, but those figures are unnamed ("the Wise") or otherwise unknown in the biblical tradition (Lemuel, Agur). We might, then, understand the profound intertextual effect the Solomonic titles of Proverbs may have the effect such a title has, even without a narrative of performance or transmission, when it invokes the tradition of Solomon's composition of many משלים. The titles of Proverbs, both the title in 1:1 and the titles for the internal collections, when read against the background of how instruction collections are typically framed, have the effect of marking the medium of the text itself, and not the legendary figure as its teacher. ${ }^{54}$ The ancient reader, knowledgeable of literary conventions, might understand the words contained within the minimalistic frame to be bound not to a speaker in the past, but to the medium itself.

\section{Capitalizing on Solomon's Abundance}

The titles of Proverbs, Song of Songs, Ecclesiastes, and Psalms (Fig. 4) demonstrate a similar framing strategy. These titles provide no narrative context for the poem's composition or performance, but they nevertheless associate the words with a legendary figure. In Song of Songs and Ecclesiastes, the titular figure appears as a named character (Song 8:12) or even a speaking voice (Eccl. 1:12) in the framed text itself. But in Proverbs this is not the case: Solomon, as the named individual in the title, only appears elsewhere in other collection titles in the work (Prov. 10:1; 25:1). Nevertheless, the titles of the third frame type (Fig. 4) do not provide a narrative frame - whether minimal or more extensive - in which the named figure speaks. In the case of these simple, nonnarrative frames, the named figures do not speak from their title, but their legendary personae are attached to multiple compositions, without any real claim of authorship being made. There are works outside of the Hebrew Bible that make Solomonic claims, for example the Wisdom of Solomon, the Odes of Solomon, even non-biblical works that take up a Solomonic voice, such as the medieval Old English dialogue Solomon and Marcolf.

The tradition of Solomon's excess of words is connected to the abundance those words claim to bring. This abundance of speech (and speech of abundance) makes space for endless compositions under the aegis of the Solomonic persona. It is this very abundance that the figure of Solomon enjoyed in

54 I made a similar claim in "The Book of Proverbs and the Idea of Ancient Israelite Education," p. 17 . 
biblical titles and the history of text production that brings us back to the text of "David's Compositions" in the Psalms Scroll from Qumran and its suspiciously Solomonic character. David, in the biblical literary tradition, in biographical accounts, is not a figure of abundance. But in "David's Compositions," the figure of David appropriates Solomon's characteristic prolific wisdom. What this might mean for the figure of David is outside of the scope of this particular essay. Perhaps one might venture to say that the claim made for David is that the composing of psalms is also an endless activity, or that these psalms may also generate the abundance that wisdom promises.

However, it is within the scope of this study to consider what David's appropriation of Solomon's characteristic abundance can tell us about the role biography plays in attribution. Non-narrative titles like the Solomonic titles of Proverbs tell us that even a narrated moment of performance need not figure into the frame to contextualize its words. Even without a speaker, the Solomonic titles of Proverbs designate an "ideal speaker," because this title draws upon literary tradition. When "David's Compositions" appropriates biographical elements of Solomon to describe David, what the text in fact accomplishes is it allows David, the legendary "author," the promise of abundance that only Solomon has in the tradition. We might think further about what it means in the biblical literary tradition that "Solomon composed three-thousand משל," and "David composed three-thousand six-hundred תהלים," or that Solomon's compositions add up to four thousand and five, but David's to four thousand and fifty. When David appropriates Solomon's characteristic qualities, and David's number of compositions just eclipse those of Solomon, perhaps this is one way biblical genres encroach upon and reshape one another. 